\title{
Ecological Flow Assessment to Improve the Spawning Habitat for the Four Major Species of Carp of the Yangtze River: A Study on Habitat Suitability Based on Ultrasonic Telemetry
}

\author{
Lixiong Yu ${ }^{1,2}$, Junqiang Lin ${ }^{3}$, Daqing Chen ${ }^{1,2, *}$, Xinbin Duan ${ }^{2, *}$, Qidong Peng ${ }^{3}$ \\ and Shaoping Liu $^{2}$ \\ 1 Key Laboratory of Freshwater Fish Reproduction and Development (Ministry of Education), \\ Key Laboratory of Aquatic Science of Chongqing, School of Life Science, Southwest University, \\ Chongqing 400715, China; Yulx99@126.com \\ 2 Yangtze River Fisheries Research Institute, Chinese Academy of Fishery Science, Wuhan 430223, China; \\ Lsp@yfi.ac.cn \\ 3 China Institute of Water Resources and Hydropower Research, Bejing 100038, China; \\ Junqiang-lin@hotmail.com (J.L.); Pengqd@iwhr.com (Q.P.) \\ * Correspondence: Chdq@yfi.ac.cn (D.C.); Duan@yfi.ac.cn (X.D.); Tel.: +86-027-8178-0058 (D.C.); \\ +86-027-8178-0131 (X.D.)
}

Received: 10 March 2018; Accepted: 30 April 2018; Published: 4 May 2018

\begin{abstract}
Four major species of Chinese carp, namely black carp (Mylopharyngodon piceus), grass carp (Ctenopharyngodon idellus), silver carp (Hypophthalmichthys molitrix) and bighead carp (Hypophthalmichthys nobilis), are important economic freshwater fish varieties in China. They primarily inhabit and breed in the Yangtze River. Unfortunately, the construction and operation of the Gezhouba Dam and the Three Gorges Dam have dramatically changed the hydrodynamic conditions in the middle reaches of the Yangtze River, leading to a sharp decline in the reproduction rates of these carp. The egg abundance of the four species of carp downstream from the Three Gorges Dam reached 8.35 billion in 1965 , but abundance during 2005-2012 was only 0.25 billion. One of the main reasons was that the hydrodynamic conditions of the spawning ground could not meet the four species' breeding requirements. However, due to the limitations of traditional detection tools, the spawning characteristics of these four species of carp were still unclear. In this study, the ultrasonic telemetry and a three-dimensional hydrodynamic model were utilized to build the habitat suitability index (HSI) curves for the four species of carp. The habitat suitability model was then built based on HSI curves to assess spawning habitat quantity under different flow conditions. Finally, the habitat suitability model in the Yidu spawning ground was validated using 32 groups of sampling data in 2015 and 2017. The statistical results showed that the most suitable velocity ranged from $0.78 \mathrm{~m} / \mathrm{s}$ to $0.93 \mathrm{~m} / \mathrm{s}$. The most suitable water depth ranged from $14.56 \mathrm{~m}$ to $16.35 \mathrm{~m}$, and the most suitable Froude number ranged from 0.049 to 0.129 . The habitat suitability model simulation results indicated that when the discharge was between $15,000 \mathrm{~m}^{3} / \mathrm{s}$ and $21,300 \mathrm{~m}^{3} / \mathrm{s}$, the weighted usable area (WUA) values in both the Yidu and Zhicheng spawning grounds would remain at a high level. The validation results showed that most spawning activities occurred at a high level of WUA, and that the daily spawning egg numbers increased with the WUA value. Therefore, discharges of between $15,000 \mathrm{~m}^{3} / \mathrm{s}$ and $21,300 \mathrm{~m}^{3} / \mathrm{s}$ could be recommended as ecological operation target flows. We propose a feasible ecological operation scheme by setting the initial flow at $15,000 \mathrm{~m}^{3} / \mathrm{s}$ and maintaining the daily discharge increase at $1500 \mathrm{~m}^{3} / \mathrm{s}$ for 4 days.
\end{abstract}

Keywords: four major Chinese carps; spawning ground; ultrasonic telemetry; habitat suitability index model; ecological flow 


\section{Introduction}

The four major species of Chinese carp, i.e., black carp (Mylopharyngodon piceus), grass carp (Ctenopharyngodon idellus), silver carp (Hypophthalmichthys molitrix) and bighead carp (Hypophthalmichthys nobilis), play important roles in both cultivation and capture fishery nationwide [1]. Although these four carp species are widely distributed throughout many Chinese rivers, the Yangtze River is the most important habitat [2]. Adult fish migrate upstream to spawn during the spawning season (May-July) [3,4]. The fertilized eggs drift with the current for hundreds of kilometers until they develop to larvae that can swim freely $[3,5]$. Many previous studies have investigated spawning, and its requirements are well understood: the lowest water temperature for spawning is $18{ }^{\circ} \mathrm{C}$, and the most suitable spawning temperatures are between $22{ }^{\circ} \mathrm{C}$ and $24{ }^{\circ} \mathrm{C}$; an increase in the river flow is the key spawning trigger [6-8].

The spawning grounds of the four major species of Chinese carp are located mainly in the upper and middle reaches of the Yangtze River. Historically, there were 36 spawning grounds distributed in the main stream of the Yangtze River, which were located from Chongqing to Pengze within a range of $1695 \mathrm{~km}$ [4]. The annual total egg production in these spawning grounds was over 100 billion [4]. However, the construction of the Gezhouba Dam in 1981 and the Three Gorges Dam in 2003 has remarkably changed downstream hydrological conditions, and led to a sharp decline in the suitable spawning area of the four carp species. The spawning activities of these four species of carp have been severely impacted [9-11]. According to field surveys, egg abundance of the four major Chinese species of carp in the Yidu section of the Yangtze River were 7.74 and 8.35 billion in 1964 and 1965 [4], but only 1.11 billion in 1981 [12]. After the completion of the Three Gorges Dam, egg abundance of these four species of carp was only 0.003-0.585 billion during 2005-2012 [11]. Egg abundance has shown a distinctive decreasing tendency.

Previous studies have shown that fish habitat was mainly influenced by both hydrological conditions and the physical characteristics of a river channel. Flow was considered to be the most important factor influencing fish habitat, since it determined a series of factors such as water level, depth, velocity, etc. [13-15]. In an attempt to alleviate the impact of river flow alterations caused by dams, creating hydrological processes similar to the natural state had been suggested as an effective measure to stimulate spawn in the four species of carp [16]. In recent years, the Three Gorges Reservoir has created artificial flood processes by ecological operation experiments, to facilitate spawning activities. Monitoring data showed that during the dam ecological operations, egg production of the four species of carp in Yidu section was 131 million, 515 million and 131 million in 2011, 2012 and 2013, respectively [9,17]. Ecological flow has been shown to be essential to conserve fish habitat [18]. However, there is still a lack of scientific analysis of the suitable habitat for the four major Chinese species of carp in response to different flow conditions.

Establishing an appropriate model to evaluate available habitat was an effective method to guide conservation efforts for aquatic organisms [19-22]. Since the four major species of Chinese carp would carry out large-scale breeding activities during dam ecological operation [17], the conditions for the presence of the adult fish during the spawning period could reflect its preferred spawning conditions to some extent [14]. This study took the four major species of Chinese carp's typical spawning grounds in Yidu and Zhicheng as study areas. A three-dimensional hydrodynamic model was built and used to simulate the flow characteristics of spawning grounds during ecological operation and under different gradients of flow. With the combination of the positioning information of spawning fish offered by ultrasonic telemetry and hydrodynamic simulation results, we used the statistical method to build key hydrodynamic suitability curves (including flow velocity, water depth, and Froude number) for the four species of carp. Finally the habitat suitability model was built based on hydrodynamic suitability curves to assess spawning habitat quantity under different flow conditions. Then the most suitable 
flow characteristics for the Chinese carp's spawning activities could be obtained. The results would provide theoretical and technological support for spawning ground evaluation and recovery, as well as fish resource protection.

\section{Materials and Methods}

\subsection{Study Area}

The middle Yangtze River, which is about $898 \mathrm{~km}$ long (from Yichang to Hukou), is the main reproduction area for the four species of carp. The $380 \mathrm{~km}$ reach from Yichang to Chenglingji is one of the most important habitats. In this section, there were 11 spawning grounds recorded for the study carps, and these spawning grounds together shared $42.7 \%$ of the total fish larvae production in the Yangtze River [9]. The study sites were in the Yidu reach and Zhicheng reach of the Yangtze River (Figure 1) $[9,11]$. The Yidu spawning ground is about $58 \mathrm{~km}$ downstream from the Three Gorges Dam, and $20 \mathrm{~km}$ downstream from the Gezhouba Dam. The Zhicheng spawning ground is about $30 \mathrm{~km}$ downstream of the Yidu spawning ground. The Yidu spawning ground is about $12 \mathrm{~km}$ long and covers an area of $15.30 \mathrm{~km}^{2}$. The Zhicheng spawning ground is about $14 \mathrm{~km}$ long and covers an area of $14.01 \mathrm{~km}^{2}$. There are two adjacent gauge stations. The Yichang gauge station is $6 \mathrm{~km}$ downstream from the Gezhouba Dam, and the Zhicheng gauge station is $65 \mathrm{~km}$ downstream from the Gezhouba Dam.

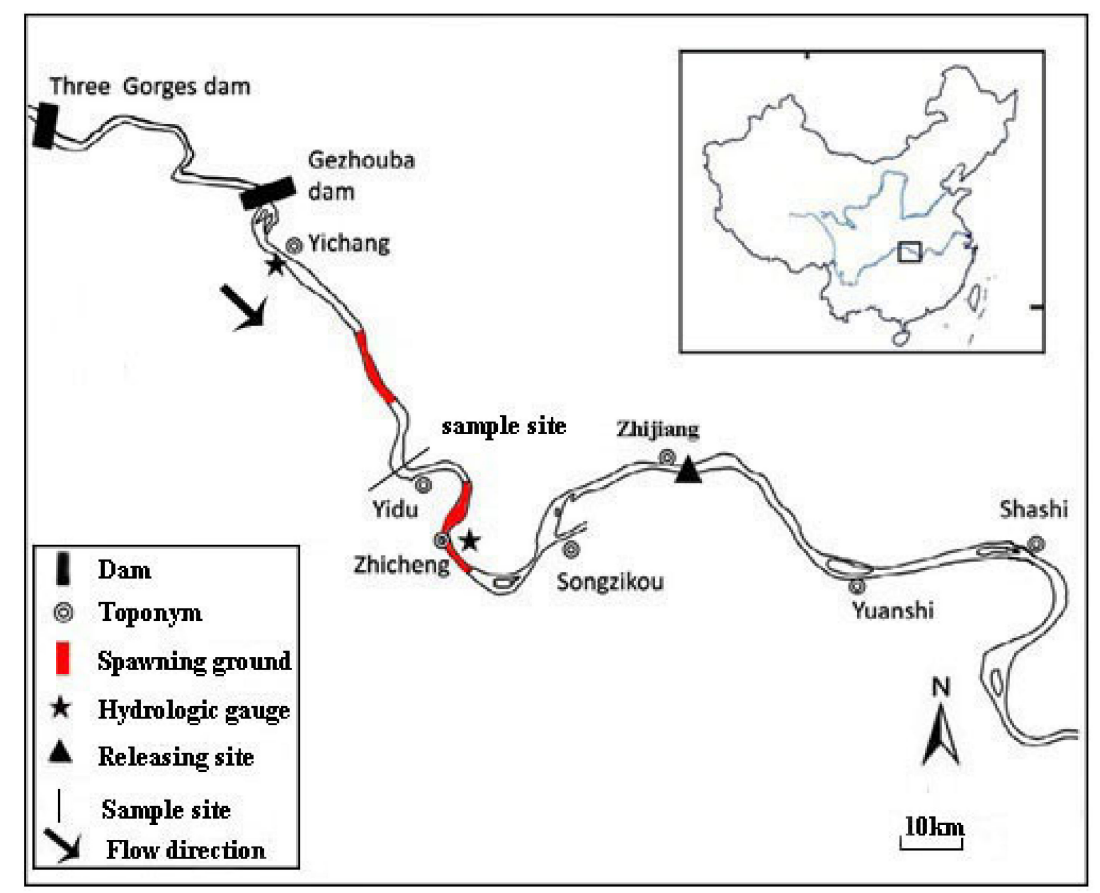

Figure 1. Location of the studied spawning grounds of the four major species of Chinese carp in the middle reach of the Yangtze River.

\subsection{Data Collection}

River cross sectional bathymetry was measured at $100 \mathrm{~m}$ intervals in the study area using an Acoustic Doppler Current Profiler (ADCP, WHR600, USA) in 2015 (Figure 2a,b). Daily water discharge and water level data of spawning grounds were obtained from Yichang and Zhicheng gauge stations (Figure 1). The egg abundance data of the four major species of Chines carp in the Yidu spawning ground were monitored by Yangtze River Fisheries Research Institute in 2015 and 2017. 


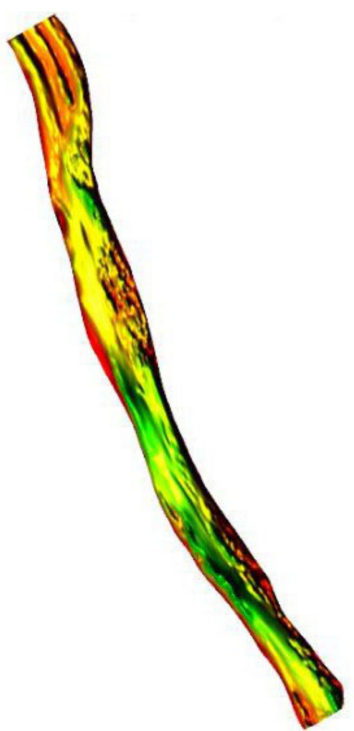

(a)

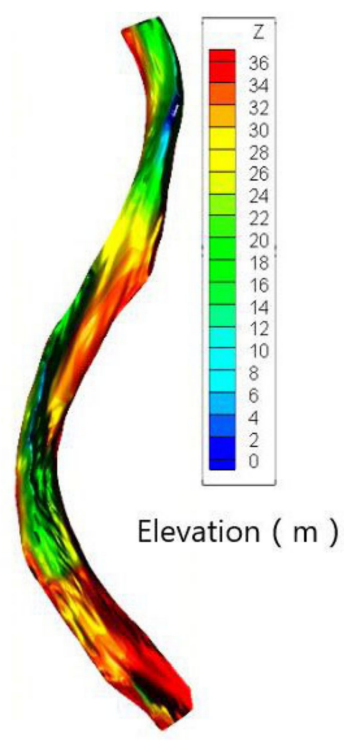

(b)

Figure 2. Bathymetry map of the four major species of Chinese carp's spawning ground. (a) the Yidu spawning ground; (b) the Zhicheng spawning ground.

\subsection{Fish Tracking Using Ultrasonic Telemetry}

A total of 107 adult fish of the four carp species (length $=78.76 \pm 6.83 \mathrm{~cm} \mathrm{SE}$; weight $=12.95 \pm 2.46 \mathrm{~kg}$ ) from the National Original Breeding Farm (NOBF, Jianli, Hubei, China) were used in ultrasonic telemetry tracking. The surgical implantation of ultrasonic transmitters (Mai Vision Technologies Co., Ltd., Shanghai, China; Table 1) was conducted from April 26, 2016 to April 28, 2016. The surgery referred to the methods that were proposed by Moore et al. [23]. The tagged fish were kept in NOBF for one month to heal, and were finally released in Zhijiang reach (Figure 1) on 1 June, 2016. We deployed 24 acoustic receivers (VR2W, Vemco Ltd., Shad Bay, NS, Canada) to monitor the tagged fish in the studied spawning ground (Figure 3a,b, (C) 2018 Google).

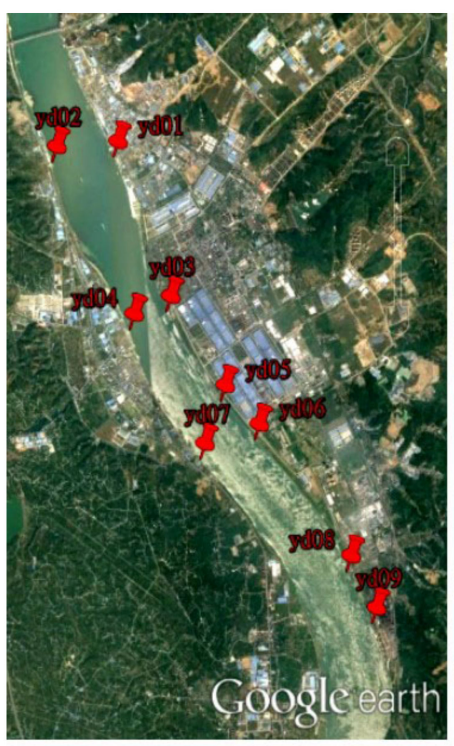

(a)

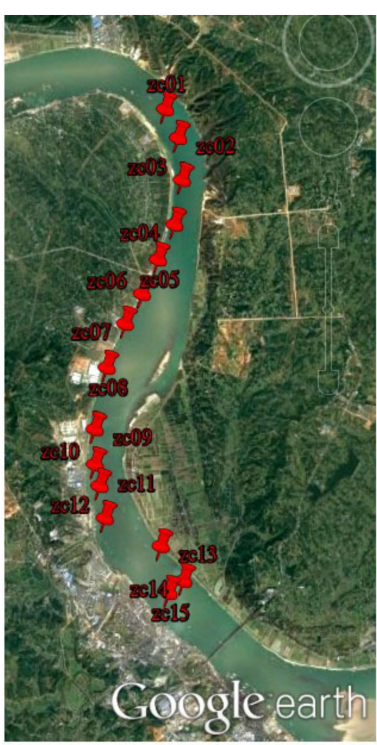

(b)

Figure 3. Map of the acoustic receiver array within the four major species of Chinese carp's spawning ground. (a) the Yidu spawning ground; (b) the Zhicheng spawning ground. 
Table 1. Number, model and specification of the ultrasonic transmitters.

\begin{tabular}{ccccccc}
\hline Model & Tag Number & $\begin{array}{c}\text { Diameter } \\
(\mathbf{m m})\end{array}$ & $\begin{array}{c}\text { Length } \\
\mathbf{( m m})\end{array}$ & $\begin{array}{c}\text { Weight in Water } \\
\mathbf{( g )}\end{array}$ & $\begin{array}{c}\text { Battery Life } \\
\mathbf{( d )}\end{array}$ & $\begin{array}{c}\text { Nominal Delay } \\
\mathbf{( s )}\end{array}$ \\
\hline V9-2L & $\begin{array}{c}77 \\
(55,127-55,203) \\
30\end{array}$ & 9.0 & 29.0 & 2.9 & 910 & 180 \\
V8-4L & $\begin{array}{c}34,540-34,569) \\
(34,0\end{array}$ & 8.0 & 20.5 & 0.9 & 210 & 120 \\
\hline
\end{tabular}

\subsection{Three—Dimensional Hydrodynamic Model}

The Yidu spawning ground was divided into $840 \times 50$ units, in which 840 sections were set along the reach, and 46 points were set across each section. And Zhicheng spawning ground was divided into $586 \times 50$ units. A three-dimensional hydrodynamic model, which was a module of the EFDC (The Environmental Fluid Dynamics Code, EFDC_Explorer 8.2, Dynamic Solutions International, LLC., Edmends, WA, USA), was established according to the flow, water levels and bathymetry (Figure 2a,b) to simulate the hydrologic processes during the two ecological operations and in seven gradients of flow: $6000 \mathrm{~m}^{3} / \mathrm{s}, 10,000 \mathrm{~m}^{3} / \mathrm{s}, 15,000 \mathrm{~m}^{3} / \mathrm{s}, 20,000 \mathrm{~m}^{3} / \mathrm{s}, 25,000 \mathrm{~m}^{3} / \mathrm{s}, 30,000 \mathrm{~m}^{3} / \mathrm{s}$ and $35,000 \mathrm{~m}^{3} / \mathrm{s}$. Since the EFDC model is not continuous in the $\mathrm{Z}$ dimension, we divided the $\mathrm{Z}$ dimension into five water layers. The model was calibrated and verified using the depth-averaged velocity of a cross-section in the Zhicheng spawning ground. A total of 12 cross-sections (Figure 4) in the Zhicheng spawning ground were measured by ADCP on 22 June, 2016. Comparisons between the model simulations and measurements of the depth-averaged velocity indicated the EFDC model allowed us to simulate the hydrologic process (Figure 5).

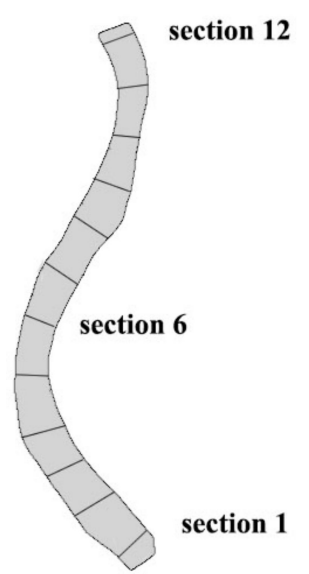

Figure 4. Distribution of the comparison cross-sections in the Zhicheng spawning ground.

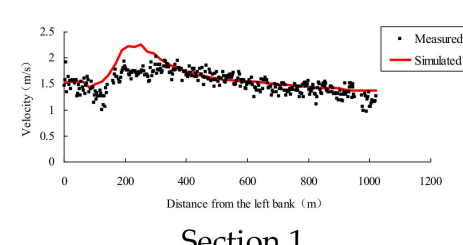

Section 1

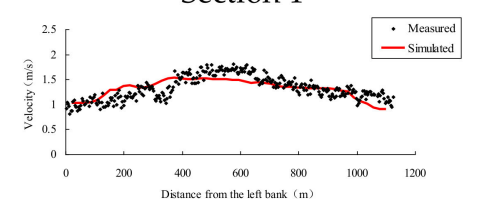

Section 4

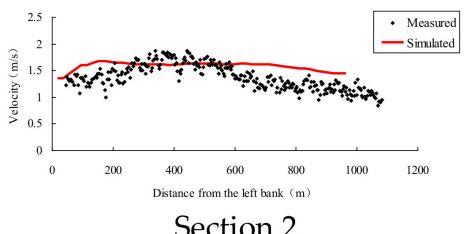

Section 2

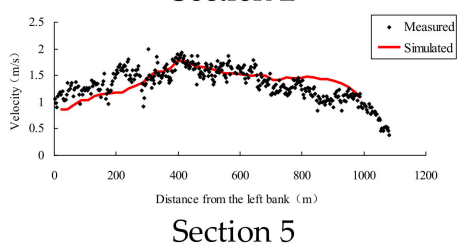

Section 5

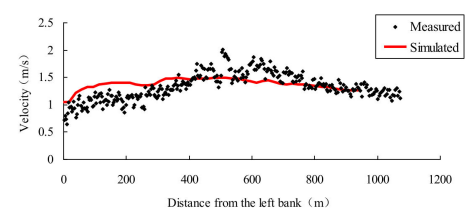

Section 3

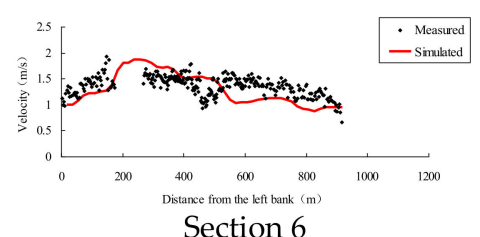

Figure 5. Cont. 


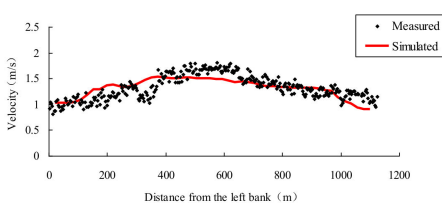

Section 7

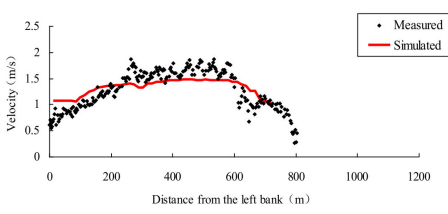

Section 10

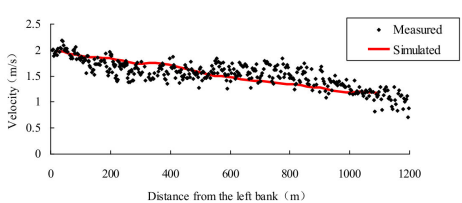

Section 8

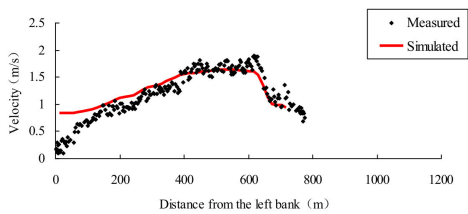

Section 11

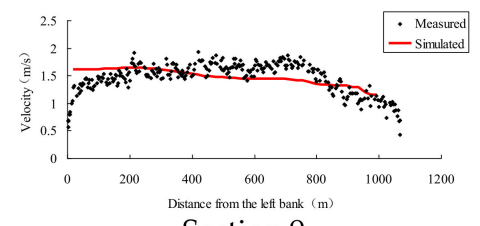

Section 9

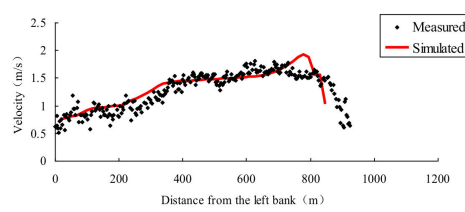

Section 12

Figure 5. Validation of simulated depth-averaged velocity in the Zhicheng spawning ground.

\subsection{Eggs Sampling}

The spawning season of the four major species of Chines carp is May-July in the middle reaches of the Yangtze River. Therefore, eggs were collected in the Yidu section (Figure 1) from 6 May to 2 July, 2015 and from 1 May to 11 July, 2017. Sampling was conducted twice daily between 5:00 AM and 9:00 AM, and between 16:00 PM and 18:00 PM. Each collection lasted for $60 \mathrm{~min}$. The eggs sampling methods and the total numbers of eggs calculation formula were proposed by Li et al. [11]. Water temperature, dissolved oxygen (DO) and pH were measured on each of the sampling occasion in 2015 (Figures 6-8).

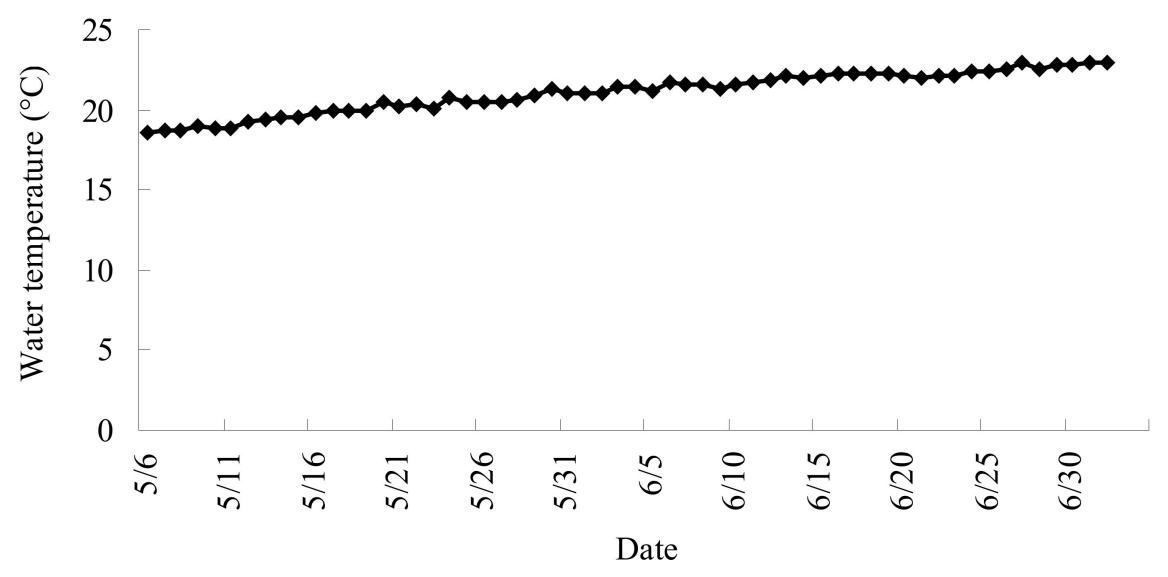

Figure 6. Water temperature of the Yidu spawning ground from 6 May to 2 July 2015.

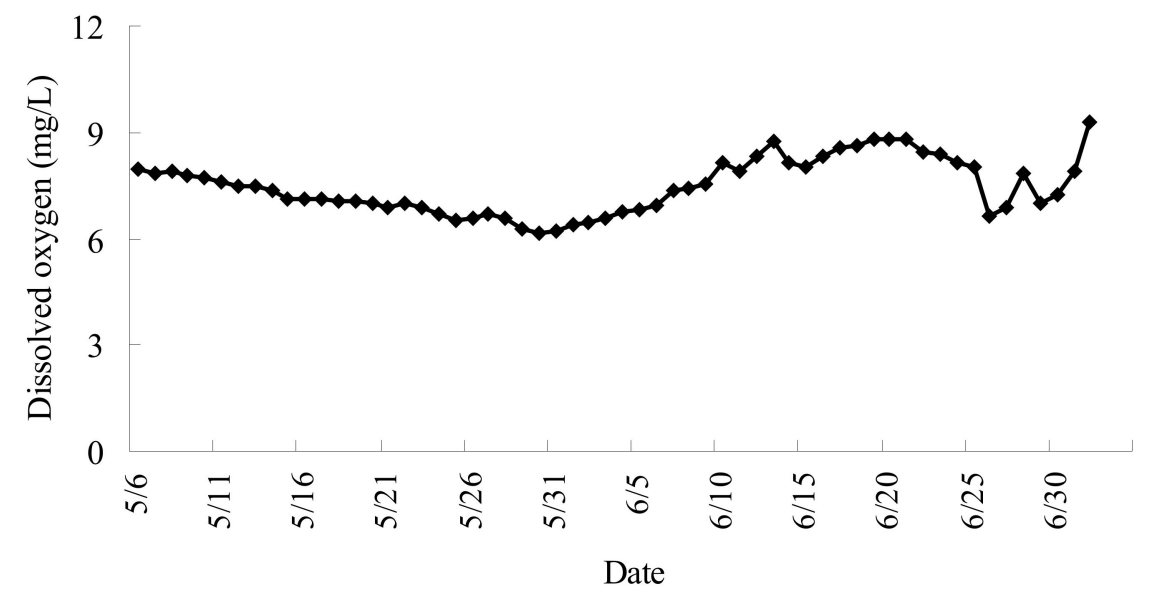

Figure 7. Dissolved oxygen in the Yidu spawning ground from 6 May to 2 July 2015. 


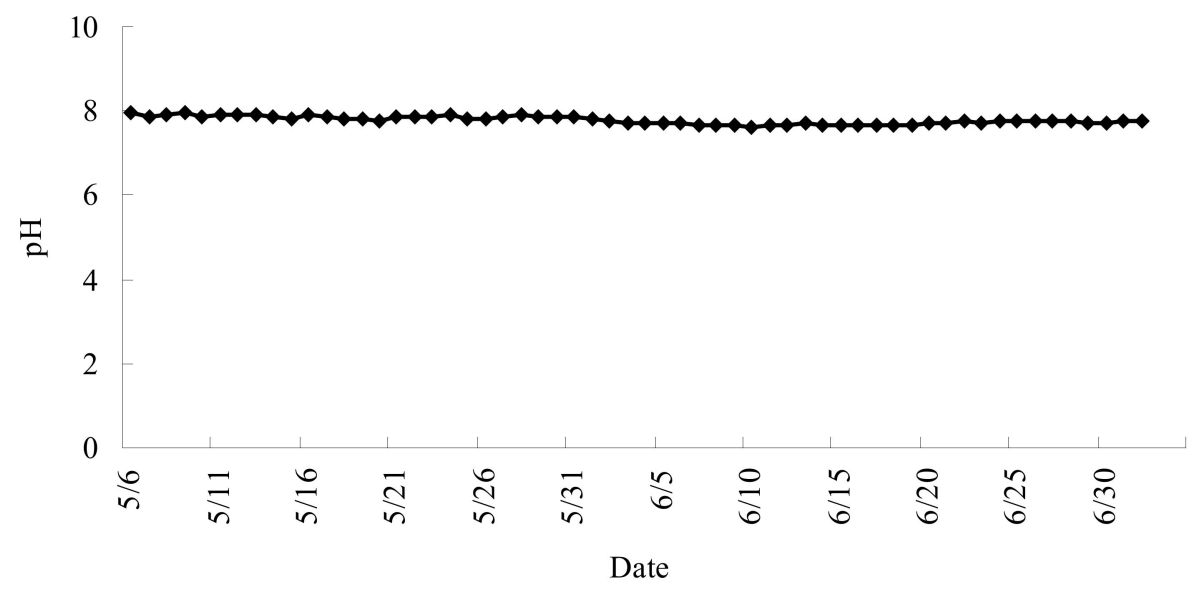

Figure 8. pH of the Yidu spawning ground from 6 May to 2 July 2015.

\subsection{Habitat Suitability Index}

The most important issue when developing the habitat suitability model was that of selecting which variables should be taken into account. The ideal model should be simple and rely on only a few key variables [22]. According to the field survey, flow and temperature were the most important factors for the reproduction of the carp. While temperature was steady, and some other important factors such as dissolved oxygen (DO) and $\mathrm{pH}$ were within a suitable range during the spawning season $[6,14]$, the habitat suitability index (HSI) of the four carp species was mainly characterized by eco-factors associated with flow. Velocity, water depth and Froude number (Fr) were taken to be closely related to reproduction rates in the target species [24].

Field monitoring showed that the ecological operation would induce large scale spawning activity. A three-dimensional hydrodynamic model was built and used to simulate the flow characteristics of the spawning ground during the ecological operation. According to Wang's study, the acoustic receiver's detection range was $495 \mathrm{~m}$ in the Yangtze River [25]. We calculated the average values of velocity, water depth, and $\mathrm{Fr}$ in the detection range corresponding to positioning information of breeding parents, then analyzed the magnitude and frequency of the velocity, water depth, and Fr values, and finally built the HSI curves of the four major species of Chinese carp.

Taking the spawning characteristics of the four species of carp into account, a HSI function was established. Since a geometric mean gave a more conservative estimate of habitat suitability by allowing the HSI to go to zero if any of the HSI values incorporated in the geometric mean were zero, it was used instead of an arithmetic mean. HSI is calculated as follows:

$$
H S I_{i}=\left(I_{V i} I_{D i} I_{F i}\right)^{\frac{1}{3}}
$$

where $i$ is the order number of a cell; $H S I_{i}$ is the corresponding habitat suitability index value of the $i$ th cell; $I_{V i}$ is the velocity suitability value of the $i$ th cell; $I_{D i}$ is the depth suitability value of the $i$ th cell; $I_{F i}$ is the Fr suitability value of the $i$ th cell.

\subsection{Weighted Usable Area}

Weighted usable area (WUA, $\mathrm{m}^{2}$ ) is a quantitative evaluation of usable habitat for a target species at a certain discharge levels [26]. The computational formula of the WUA is as follows:

$$
W U A=\sum_{i=1}^{n} A_{i} H S I_{i}
$$


where, $n$ is the number of all cells; $A_{i}\left(\mathrm{~m}^{2}\right)$ is the area of cell $i$; and $H S I_{i}$ is the corresponding habitat suitability index value of cell $i$.

For a given discharge, $\mathrm{Q}\left(\mathrm{m}^{3} / \mathrm{s}\right)$, the depth-averaged water velocity, water depth, and $\mathrm{Fr}$ of each computational cell were computed through the three-dimensional hydrodynamic model [24]. Then the WUA corresponding to a given discharge was computed by the Geographic Information System (GIS, ArcMap 10.3, Environmental Systems Research Institute Inc., Redlands, CA, USA) [22]. Finally, a curve corresponding to the flow and WUA was established by computing the WUA under a series of discharges.

\section{Results}

\subsection{The Positioning Information}

The statistics of positioning data of the four major species of Chines carp in the Yidu and Zhicheng spawning grounds were made during two ecological operations (from 8 June to 12 June, and from 20 June to 23 June 2016). A total of 106 positioning data are given in the supplementary material (Table S1).

\subsection{Three-Dimensional Hydrodynamic Simulation}

The hydrologic processes during the two ecological operations and in 7 flow gradients were simulated using an EFDC model. Some of the simulation results were as follows (Figures 9-11).

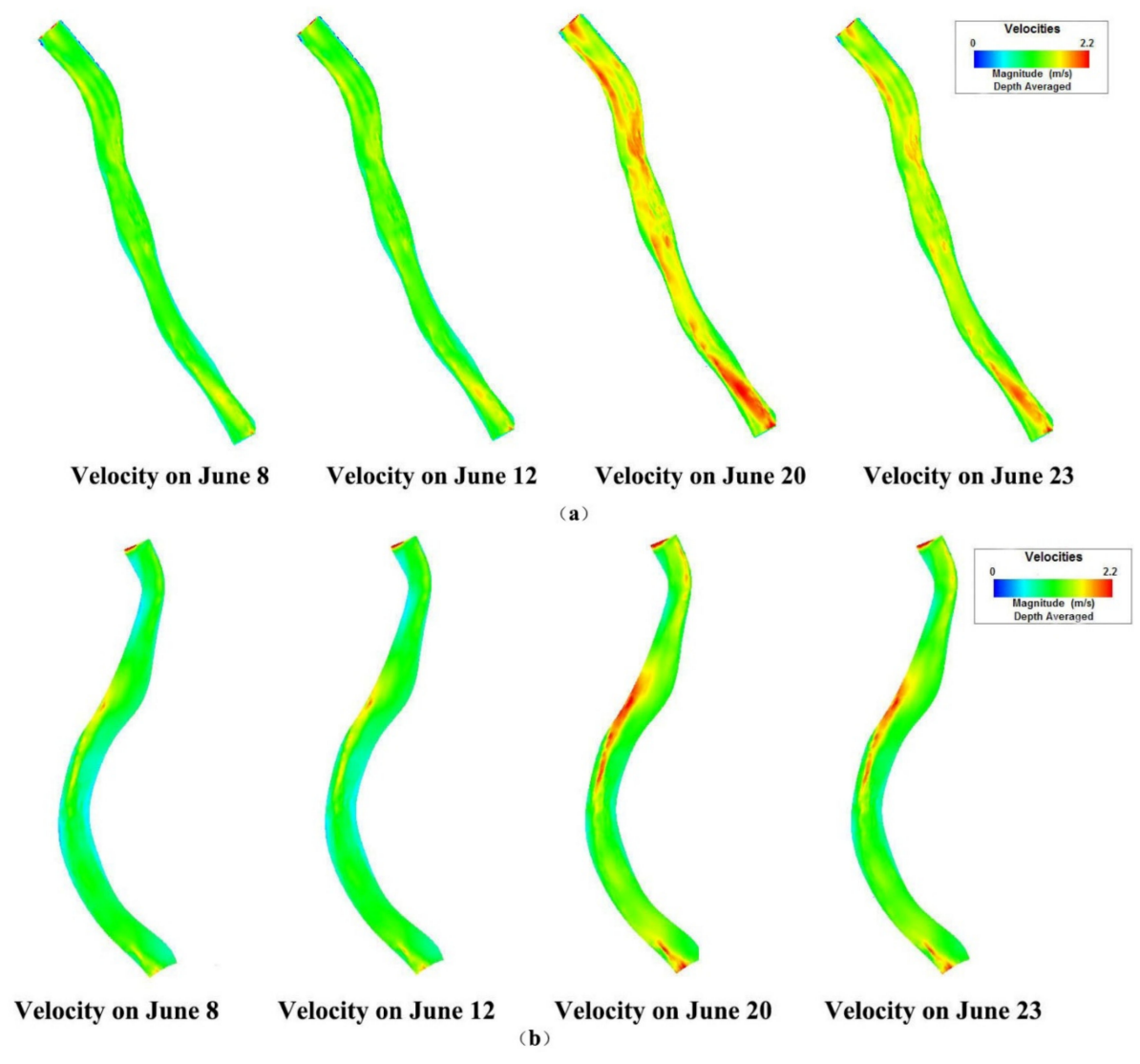

Figure 9. Water velocity on (a) the Yidu spawning ground and (b) the Zhicheng spawning ground during ecological operations in 2016. 


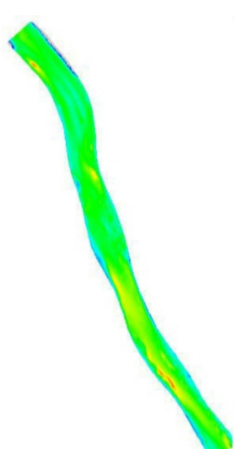

Depth on June 8

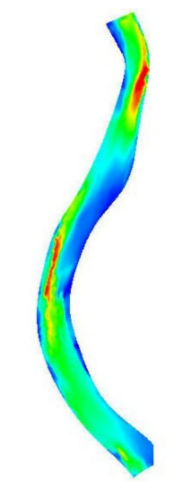

Depth on June 8

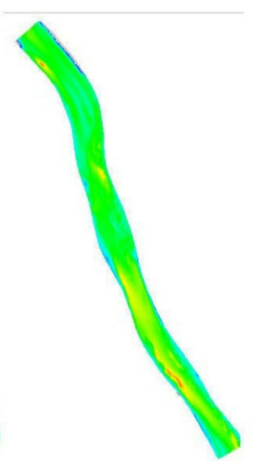

Depth on June 12

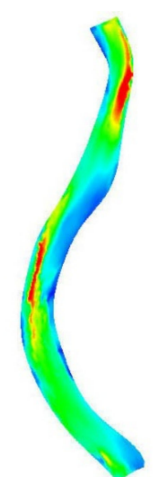

Depth on June 12

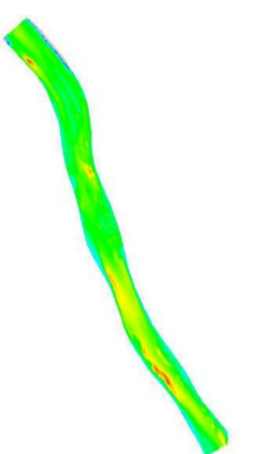

Depth on June 20

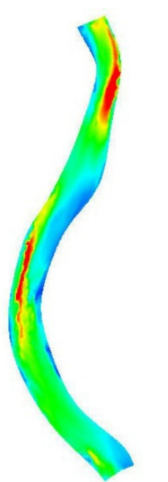

b)

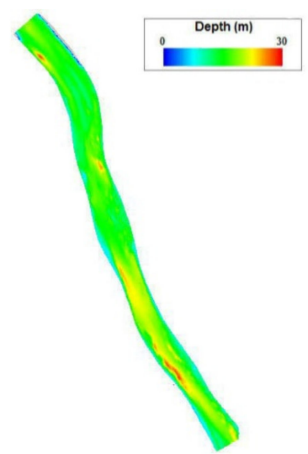

Depth on June 23

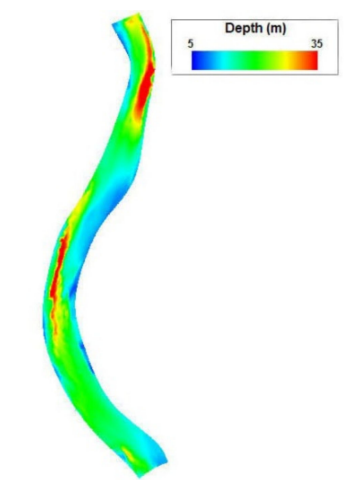

Depth on June 23

Figure 10. Water depth on (a) the Yidu spawning ground and (b) the Zhicheng spawning ground during ecological operation in 2016.

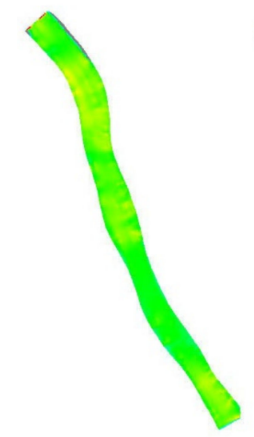

Fr on June 8

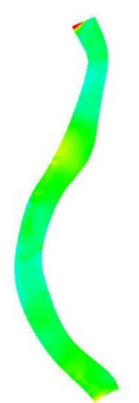

Fr on June 8

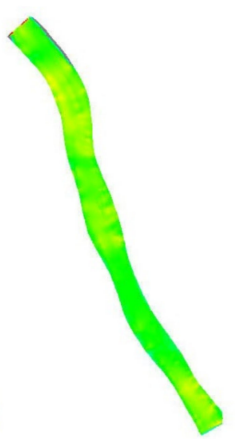

Fr on June 12

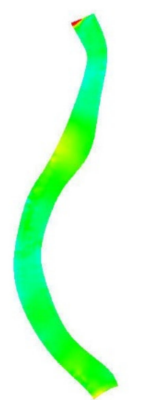

Fr on June 12

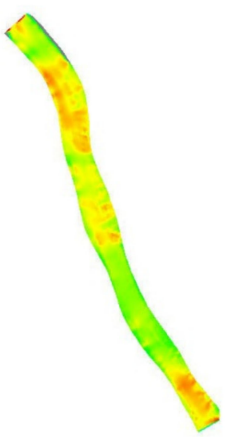

(a)

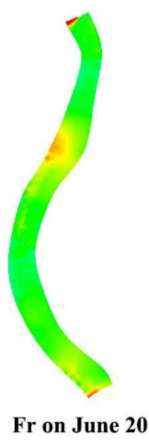

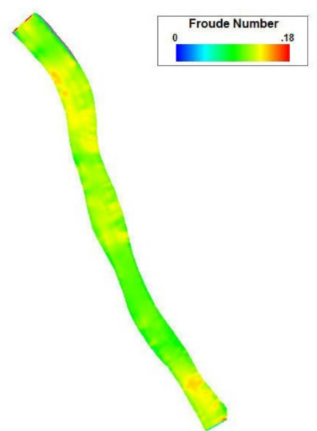

Fr on June 23

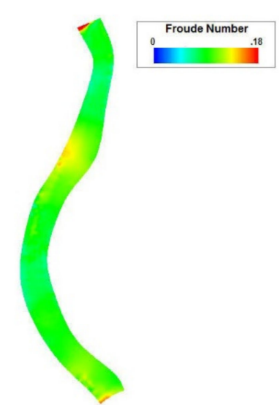

Fr on June 23

Figure 11. Froude number on (a) the Yidu spawning ground and (b) the Zhicheng spawning ground during ecological operation in 2016. 


\subsection{The Habitat Suitability Index Curves}

The following is a summary of statistics of the velocity related to the 106 monitoring data of the four major species of Chines carp during the ecological operation. The velocity of these positions was between $0.63 \mathrm{~m} / \mathrm{s}$ and $1.83 \mathrm{~m} / \mathrm{s}$. Velocity ranges of between $0.78 \mathrm{~m} / \mathrm{s}$ and $0.93 \mathrm{~m} / \mathrm{s}$ appeared most frequently, 23 times in total. Velocity distribution was normalized and the highest frequency, 23 , was assigned a suitability value of 1 . An velocity suitability curve was established for the four major species of Chines carp (Figure 12).

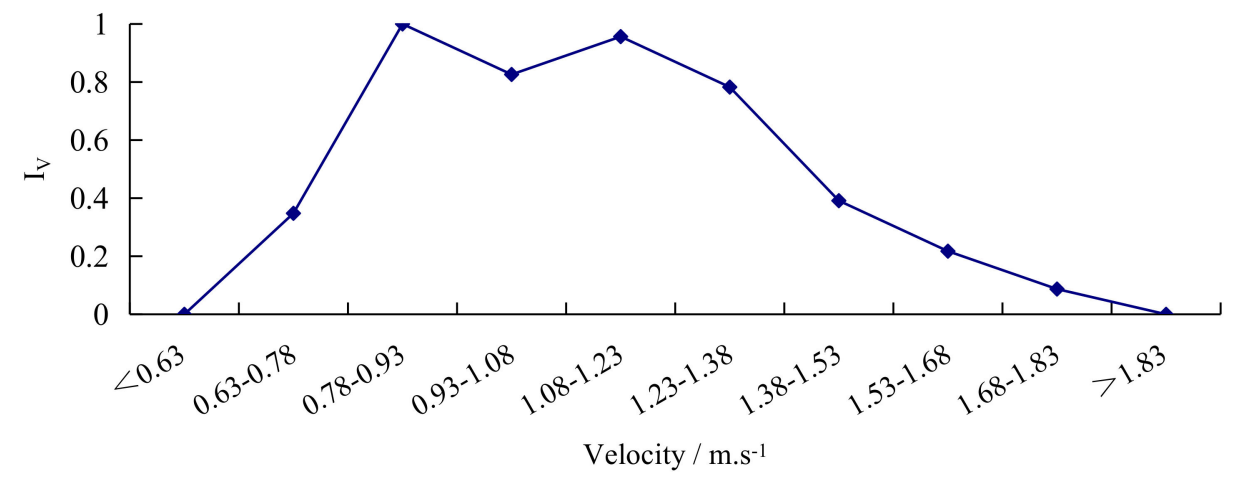

Figure 12. Velocity suitability curves for the four major Chinese carps.

The following is a summary of statistics of the water depth related to the 106 monitoring data of the four major species of Chines carp during the ecological operation. The water depth of these positions was between $10.98 \mathrm{~m}$ and $25.30 \mathrm{~m}$. Water depth ranging from $14.56 \mathrm{~m}$ to $16.35 \mathrm{~m}$ appeared most frequently, 26 times in total. Water depth distribution was normalized and the highest frequency, 26 , was assigned a suitability value of 1 . An water depth suitability curve was established for the four major species of Chines carp (Figure 13).

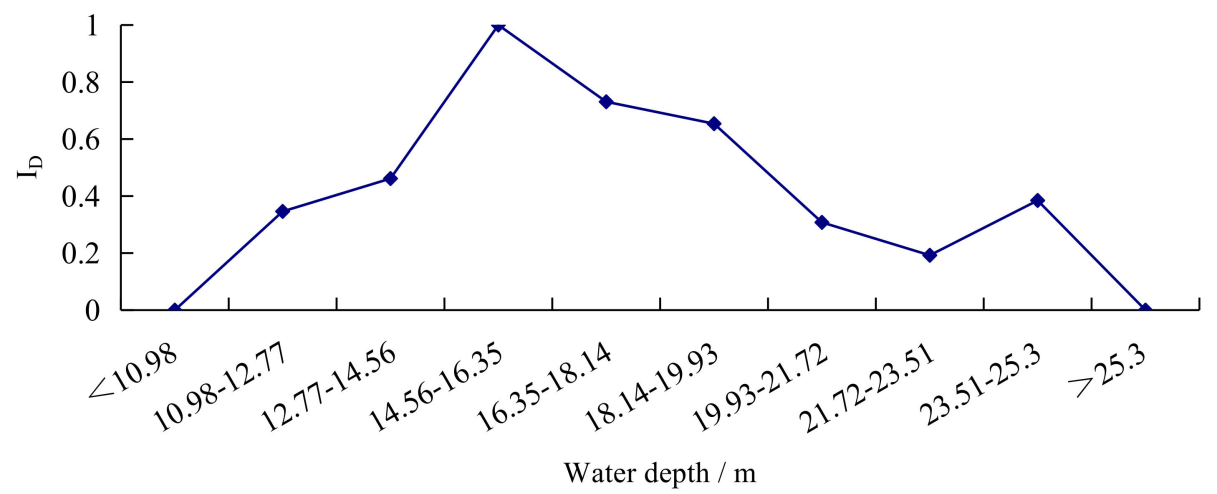

Figure 13. Water level suitability curves for the four major Chinese carps.

The following is a summary of statistics of the Fr related to the 106 monitoring data of the four major species of Chines carp during the ecological operation. The Fr of these positions was between 0.049 and 0.129 . Fr. Ranges between 0.089 and 0.099 appeared most frequently, 24 times in total. Fr distribution distribution was normalized and the highest frequency, 24, was assigned a suitability value of 1 . An Fr suitability curve was established for the four major species of Chines carp (Figure 14). 


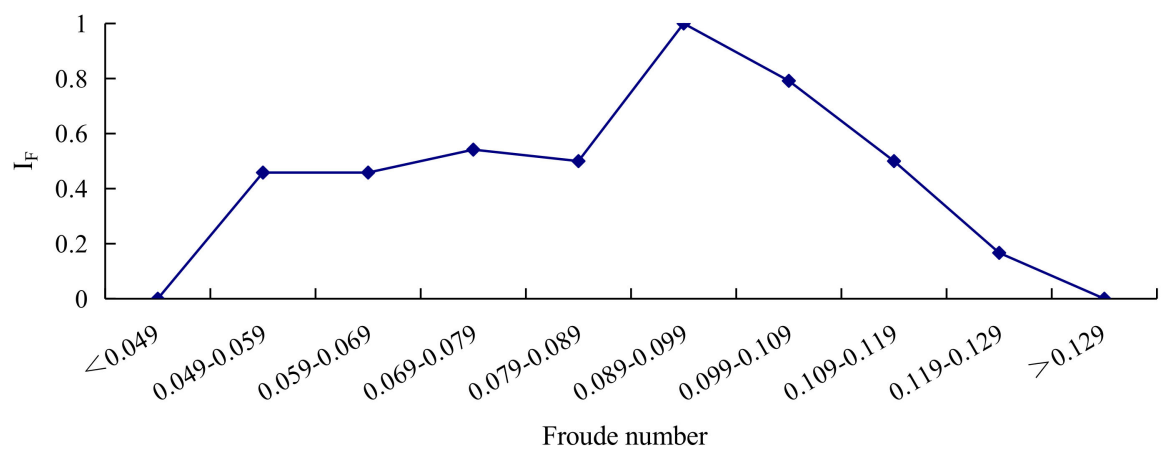

Figure 14. Froude number suitability curves for the four major Chinese carps.

\subsection{The Relationship between Discharge Level and Habitat Quality}

Figure 15 presented the habitat suitability for discharges of $6000 \mathrm{~m}^{3} / \mathrm{s}, 10,000 \mathrm{~m}^{3} / \mathrm{s}, 15,000 \mathrm{~m}^{3} / \mathrm{s}$, $20,000 \mathrm{~m}^{3} / \mathrm{s}, 25,000 \mathrm{~m}^{3} / \mathrm{s}, 30,000 \mathrm{~m}^{3} / \mathrm{s}$ and $35,000 \mathrm{~m}^{3} / \mathrm{s}$ in the Yidu (Figure 15a) and Zhicheng spawning grounds (Figure 15b). Figure 16 presents the WUA value for discharges of $6000 \mathrm{~m}^{3} / \mathrm{s}$, $10,000 \mathrm{~m}^{3} / \mathrm{s}, 15,000 \mathrm{~m}^{3} / \mathrm{s}, 20,000 \mathrm{~m}^{3} / \mathrm{s}, 25,000 \mathrm{~m}^{3} / \mathrm{s}, 30,000 \mathrm{~m}^{3} / \mathrm{s}$ and $35,000 \mathrm{~m}^{3} / \mathrm{s}$, as well as the other discharges during ecological operations.

The WUA value in the Yidu spawning ground increased when the discharges ranged from $6000 \mathrm{~m}^{3} / \mathrm{s}$ to $15,000 \mathrm{~m}^{3} / \mathrm{s}$, and decreased when the discharges ranged from $21,300 \mathrm{~m}^{3} / \mathrm{s}$ to $35,000 \mathrm{~m}^{3} / \mathrm{s}$. When the discharges ranged from $15,000 \mathrm{~m}^{3} / \mathrm{s}$ to $21,300 \mathrm{~m}^{3} / \mathrm{s}$, WUA values maintained a high level. WUA value reached a peak at a discharge rate of $15,000 \mathrm{~m}^{3} / \mathrm{s}$, indicating that a discharge of $15,000 \mathrm{~m}^{3} / \mathrm{s}$ was the most suitable for the four major species of Chines carp to spawn in the Yidu spawning ground. The WUA value in the Zhicheng spawning ground increased when discharges ranged from $6000 \mathrm{~m}^{3} / \mathrm{s}$ to $15000 \mathrm{~m}^{3} / \mathrm{s}$, and decreased when they ranged from $24,700 \mathrm{~m}^{3} / \mathrm{s}$ to $35,000 \mathrm{~m}^{3} / \mathrm{s}$. When discharges ranged from $15,000 \mathrm{~m}^{3} / \mathrm{s}$ to $24,700 \mathrm{~m}^{3} / \mathrm{s}$, WUA values maintained at a high level. WUA values peaked at a discharge of $22,500 \mathrm{~m}^{3} / \mathrm{s}$, indicating that a discharge of $22,500 \mathrm{~m}^{3} / \mathrm{s}$ was the most suitable for the four major species of Chines carp to spawn in Zhicheng spawning ground.

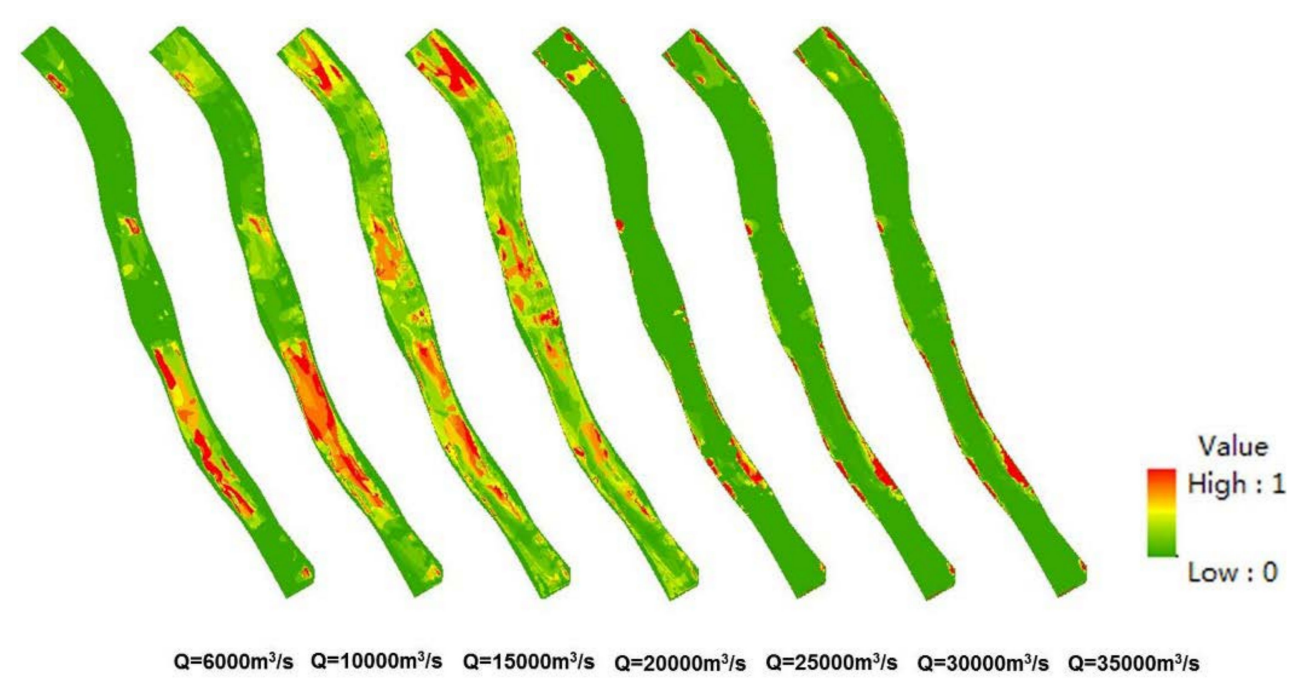

(a)

Figure 15. Cont. 


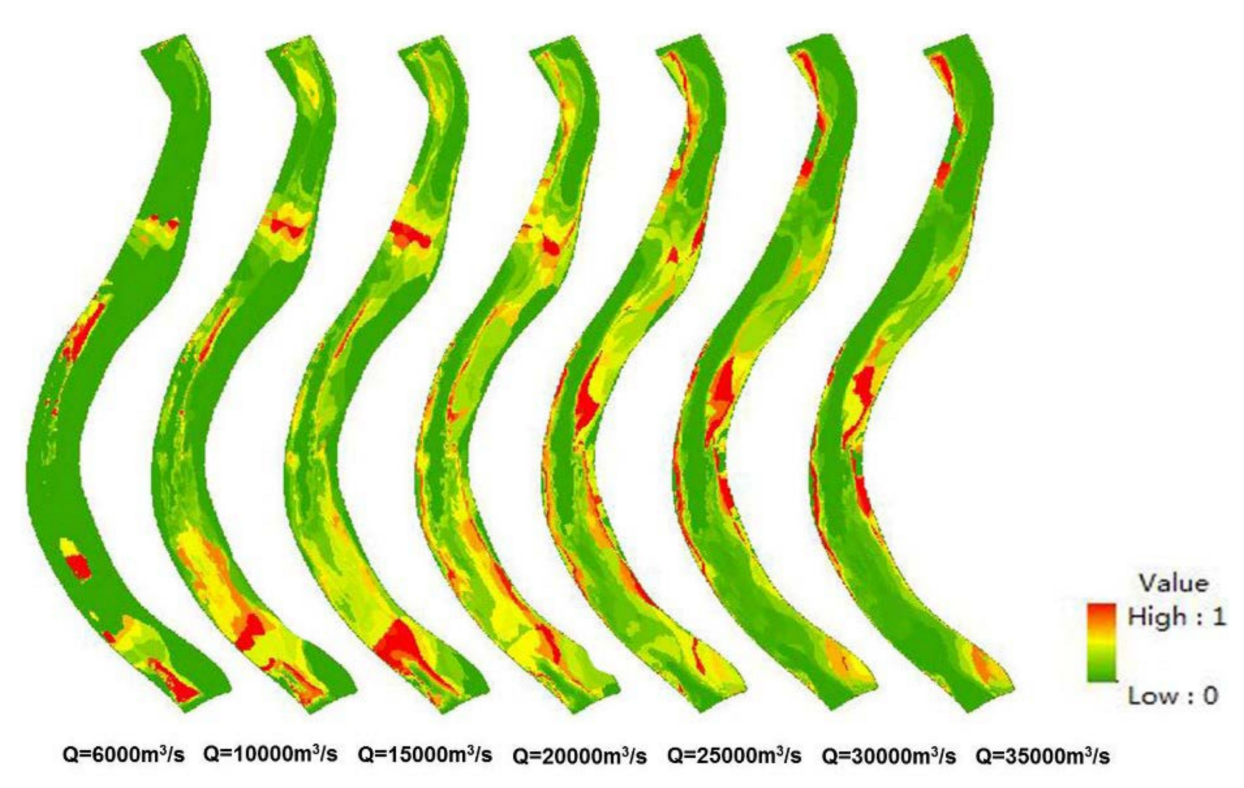

(b)

Figure 15. Habitat suitability index of the four major species of Chines carp's spawning ground for seven typical flow conditions. (a) the Yidu spawning ground; (b) the Zhicheng spawning ground.

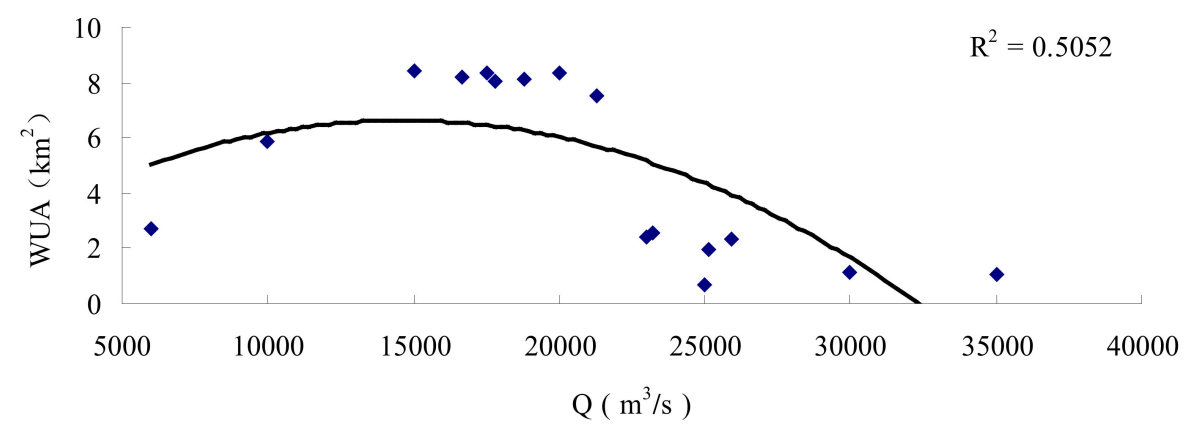

(a)

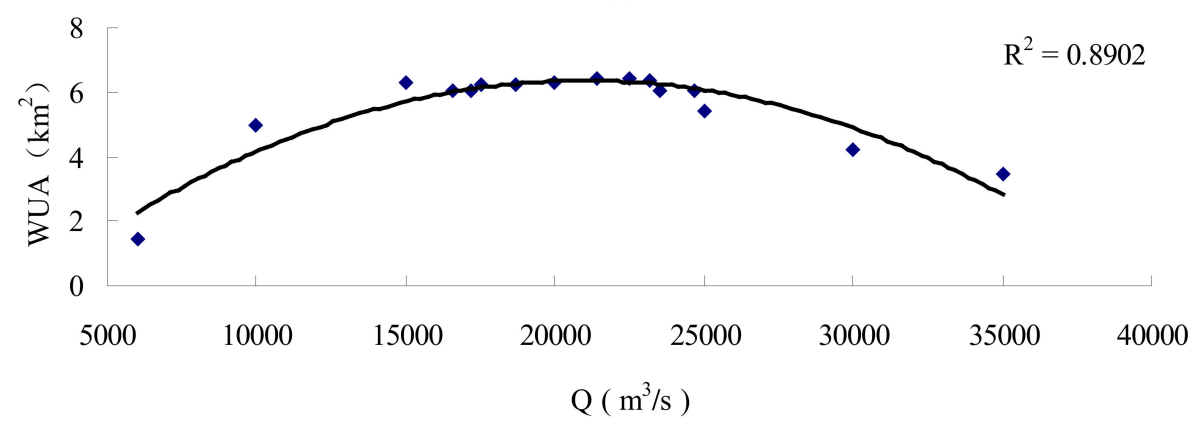

(b)

Figure 16. WUA value of the four major species of Chines carp's spawning ground for different flow conditions. (a) the Yidu spawning ground; (b) the Zhicheng spawning ground.

\subsection{Habitat Suitability Model Validation}

The habitat suitability model for the four major species of Chines carp in the Yidu spawning ground was validated using 32 groups of sampling data in 2015 and 2017 (Table S2). Figure 17 showed the relation between daily spawning egg numbers and the calculated weighted usable area. Most spawning activities occurred at a high level of WUA, and the daily spawning egg numbers increased with the WUA value. 


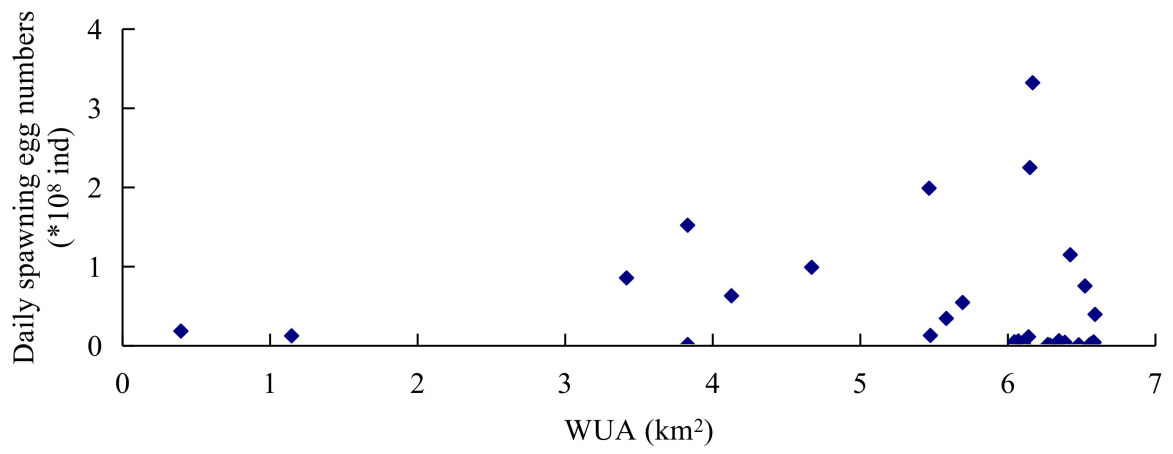

Figure 17. Relation between daily spawning egg numbers and the calculated weighted usable area at the Yidu spawning ground.

\section{Discussion}

\subsection{The Habitat Suitability Index}

The membership function of habitat suitability in some studies was obtained through fish behavior experiments in a laboratory flume [18]. However, the laboratory experiments are inadequate to simulate the behavior of fish in natural rivers. Field monitoring of fish's natural reproduction by ultrasonic telemetry was an important means to study the hydrodynamic preference of fish. Since the four major species of Chines carp would carry out large-scale breeding activities during ecological operations [17], the conditions for the presence of the adult fish during the spawning period could reflect its preferred spawning conditions to some extent [14]. According to the monitoring results for the carps' reproduction, the amount of spawning eggs had a strong positive correlation with velocity and Fr [24]. During the spawning period, the velocity of the Yidu spawning ground ranged from $0.97 \mathrm{~m} / \mathrm{s}$ to $1.31 \mathrm{~m} / \mathrm{s}$, and the Fr of the Yidu spawning ground ranged from 0.09 to 0.11 [24]. These ranges were essentially identical to the highly suitable ranges obtained by ultrasonic telemetry, which indicates that the habitat suitability index curves based on ultrasonic telemetry in the present study could accurately describe the hydraulic condition preferences of the studied carps. The habitat suitability model based on the HSI curves in the present study was generally successful for mapping the available habitat for the carp.

\subsection{The Ecological Flow}

According to historical records, discharge during the spawning season was $5711-45208 \mathrm{~m}^{3} / \mathrm{s}$ in the middle reach of the Yangtze River [11]. However, a too large or too small daily discharge was not good for carp spawning [15]. In fact, most spawning activities occurred at a high level of WUA, and the daily spawning egg numbers increased with the WUA value (Figure 17). Around $78.12 \%$ of spawning activities occured when the WUA was larger than $5 \mathrm{~km}^{2}$, and the corresponding egg production accounted for $72.61 \%$ of total egg production in the Yidu spawning ground in 2015 and 2017. According to the HSI model calculated results, the WUA values in the Yidu spawning ground remained at a high level when the discharges ranged from $15,000 \mathrm{~m}^{3} / \mathrm{s}$ to $21,300 \mathrm{~m}^{3} / \mathrm{s}$, and the suitable discharge range in the Yidu spawning ground was within the suitable range of the Zhicheng spawning ground. A discharge rate of between $15,000 \mathrm{~m}^{3} / \mathrm{s}$ and $21,300 \mathrm{~m}^{3} / \mathrm{s}$ could be recommended as ecological operation target flow.

\subsection{Operational Recommendations}

Previous studies have suggested that the simultaneous occurrence of suitable flood peaking and the flow increase, such as duration, daily increasing rate and timing, directly resulted in synchronizing the trigger for spawning events $[14,27,28]$. The optimal daily discharge increase was about $1000-2000 \mathrm{~m}^{3} / \mathrm{s}[8,14]$. However, the natural flow regime had been altered significantly after 
the construction of the Three Gorges Dam [27]. The two major changes-an increase in low flow and a decrease in high flow-made the river flow more homogenous [29]. The reduced water discharge and flood peaks has led to a significant decrease in the production of eggs for the four major species of Chines carp $[7,9,11,30]$. To reduce the adverse effects of dam operations on fish spawning, the operation procedures of the Three Gorges Reservoir should be adjusted during the spawning season to improve the habitat suitability. Many studies have indicated that flooding and water temperature played key roles in the successful spawning of the four species of carp [4,7,8]. Zeng [31] considered that increases in discharge lasting for 4-6 days were good for spawning activity, and Li et al. [7] believe the an increase in process lasting for 1-3 days would favor spawning activity. To apply our results to the ecological regulation of the Three Gorges Dam in the middle reaches of the Yangtze River, we propose a feasible ecological operation scheme by setting the initial flow at $15,000 \mathrm{~m}^{3} / \mathrm{s}$ and maintaining the daily discharge increase of $1500 \mathrm{~m}^{3} / \mathrm{s}$ for 4 days.

\section{Conclusions}

By coupling the ultrasonic telemetry positioning data and a three-dimensional hydrodynamic model, the HSI curves have been built for the four major species of Chinese carp. Results showed that the most suitable velocity ranged between $0.78 \mathrm{~m} / \mathrm{s}$ and $0.93 \mathrm{~m} / \mathrm{s}$. The most suitable water depth ranged between $14.56 \mathrm{~m}$ and $16.35 \mathrm{~m}$, and the most suitable Fr ranged between 0.049 and 0.129. A habitat suitability model was then built based on the HSI curves and the three-dimensional hydrodynamic model. According to the simulation results, when the discharge was between $15,000 \mathrm{~m}^{3} / \mathrm{s}$ and $21,300 \mathrm{~m}^{3} / \mathrm{s}$, the WUA values in both the Yidu and Zhicheng spawning grounds would remain at a high level. The habitat suitability model in the Yidu spawning ground was validated using 32 groups of sampling data in 2015 and 2017. The results showed that most spawning activities occurred at a high level of WUA, and the daily spawning egg numbers increased with the WUA value. Therefore, a discharge rate of between $15,000 \mathrm{~m}^{3} / \mathrm{s}$ and $21,300 \mathrm{~m}^{3} / \mathrm{s}$ can be recommended as an ecological operation target flow. We propose a feasible ecological operation scheme by setting the initial flow at $15,000 \mathrm{~m}^{3} / \mathrm{s}$ and maintaining a daily discharge increase of $1500 \mathrm{~m}^{3} / \mathrm{s}$ for 4 days.

Supplementary Materials: The following are available online at http:/ / www.mdpi.com/2073-4441/10/5/600/s1, Table S1: Summary of acoustic monitoring data for tagged four major species of Chines carp during ecological operation, Table S2: Daily spawning egg numbers and WUA at Yidu spawning ground.

Author Contributions: D.C. and X.D. conceived and designed this study. L.Y. and J.L. analyzed the data and drafted the manuscript. All authors contributed to editing the manuscript.

Funding: This research was funded by the National Natural Science Foundation of China (Grant NOs. 51579247 and 51409280), and the Basic Scientific Research Project of China Institute of Water Resources and Hydropower Research (Grant NO. SD0145B162017).

Acknowledgments: The authors thank Yichang Maritime Bureau for their support.

Conflicts of Interest: The authors declare no conflict of interest.

\section{References}

1. Li, S.F. A Study on Biodiversity and Its Conservation of Major Fishes in the Yangtze River; Shanghai Scientific \& Technical Publishers: Shanghai, China, 2001.

2. Liu, J.K.; Cao, W.X. Fish resources of the Yangtze River basin and the tactics for their consevation. Resour. Environ. Yangtze Basin 1992, 1, 18-23.

3. Yi, B.L.; Liang, Z.S. Natural conditions of the spawning grounds of the "domestic fishes" in Yangtze River and essential external factor for spawning. Acta Hydrobiol. Sin. 1964, 5, 1-15.

4. Yi, B.L.; Yu, Z.T.; Liang, Z.S.; Shen, S.J.; Xu, Y.G.; Chen, J.X. Gezhouba Water Control Project and Four Famous Fishes in the Yangtze River; Hubei Science and Technology Press: Wuhan, China, 1988; pp. 1-106.

5. Zhang, G.H.; Chang, J.B.; Shu, G.F. Applications of factor-criteria system reconstruction analysis in the reproduction research on grass carp, black carp, silver carp and bighead in the Yangtze River. Int. J. Gen. Syst. 2000, 29, 419-428. [CrossRef] 
6. Chen, Y.B.; Liao, W.G.; Peng, Q.D.; Chen, D.Q.; Gao, Y. A summary of hydrology and hydrodynamics conditions of Four Chinese Carps' spawning. J. Hydroecol. 2009, 2, 130-133.

7. Li, M.Z.; Gao, X.; Yang, S.R.; Duan, Z.H.; Cao, W.X.; Liu, H.Z. Effects of environmental factors on natural reproduction of the four major Chinese carps in the Yangtze River, China. Zoolog. Sci. 2013, 30, $296-303$. [CrossRef] [PubMed]

8. Wang, J.N.; Li, C.; Duan, X.B.; Chen, D.Q.; Feng, S.X.; Luo, H.H.; Peng, Q.D.; Liao, W.G. Variation in the significant environmental factors affecting larval abundance of four major Chinese carp species: Fish spawning response to the Three Gorges Dam. Freshw. Biol. 2014, 59, 1343-1360. [CrossRef]

9. Xu, W.; Qiao, Y.; Chen, X.J.; Cai, Y.P.; Yang, Z.; Liu, H.G. Spawning activity of the four major Chinese carps in the middle mainstream of the Yangtze River, during the Three Gorges Reservoir operation period, China. Appl. Ichthyol. 2015, 31, 846-854. [CrossRef]

10. Hu, M.L.; Hua, Q.; Zhou, H.M.; Wu, Z.Q.; Wu, X.P. The effect of dams on the larval abundance and composition of four carp species in key river systems in China. Environ. Biol. Fish. 2015, 98, 1201-1205. [CrossRef]

11. Li, M.Z.; Duan, Z.H.; Gao, X.; Cao, W.X.; Liu, H.Z. Impact of the Three Gorges Dam on reproduction of four major Chinese carps species in the middle reaches of the Changjiang River. J. Chin. Oceanol. Limn. 2016, 34, 888-893. [CrossRef]

12. Yu, Z.T.; Zhou, C.S.; Deng, Z.L.; Xu, Y.G. On spawning grounds of four Chinese farm fishes in the River Changjiang after damming of Gezhouba area. Trans. Chin. Ichthyol. Soc. 1985, 4, 1-12.

13. Petts, G.E. Instream flow science for sustainable river management. JAWRA J. Am. Water Resour. Assoc. 2009, 45, 1071-1086. [CrossRef]

14. Yi, Y.J.; Wang, Z.Y.; Yang, Z.F. Impact of the Gezhouba and Three Gorges Dams on habitat suitability of carps in the Yangtze River. J. Hydrol. 2010, 387, 283-291. [CrossRef]

15. Yi, Y.J.; Sun, J.; Zhang, S.H. A habitat suitability model for Chinese sturgeon determined using the generalized additive method. J. Hydrol. 2016, 534, 11-18. [CrossRef]

16. Cao, W.X.; Yu, Z.T. Preliminary assessment of impacts of the three gorges project on fish resources of the Changjiang river and approaches to the resource proliferation. In Symposium on Impacts of the Three Gorges Project on Ecology and Environment and Possible Countermeasures; Science Press: Beijing, China, 1987; pp. 3-18.

17. Chen, J.; Li, Q.Q. Assessment of eco-operation effect of the Three Gorges Reservoir during trial run period. J. Yangtze River Sci. Res. Inst. 2015, 32, 1-6. [CrossRef]

18. Li, W.M.; Chen, Q.W.; Cai, D.S.; Li, R.N. Determination of an appropriate ecological hydrograph for a rare fish species using an improved fish habitat suitability model introducing landscape ecology index. Ecol. Model. 2015, 311, 31-38. [CrossRef]

19. Gibson, R.N. Impact of habitat quality and quantity on the recruitment of juvenile flatfishes. Neth. Sea Res. 1994, 32, 191-206. [CrossRef]

20. Norcross, B.L.; Mutter, F.; Holladay, B.A. Habitat models for juvenile pleuronectids around Kodiak Island, Alaska. Fish. Bull. 1997, 95, 504-520.

21. Brown, S.; Buja, K.; Jury, S.; Monaco, M.; Banner, A. Habitat suitability index models for eight fish and invertebrate species in Casco and Sheepscot Bays, Maine. N. Am. Fish Manag. 2000, 20, 408-435. [CrossRef]

22. Vinagre, C.; Fonseca, V.; Cabral, H.; Costa, M.J. Habitat suitability index models for the juvenile soles, Solea solea and Solea senegalensis, in the Tagus estuary: Defining variables for species management. Fish. Res. 2006, 82, 140-149. [CrossRef]

23. Moore, A.; Russell, I.C.; Potter, E.C.E. The effects of intraperitoneally implanted dummy acoustic transmitters on the behaviour and physiology of juvenile Atlantic salmon, Salmo salar L. J. Fish Biol. 1990, 37, 713-721. [CrossRef]

24. Bai, H.X. Analysis on Topographical Characteristics and Ecological Hydrodynamic Factors of the Four Major Chinese Carps' Yidu Spawning Ground in Yangtze River. Master's Thesis, China Institute of Water Resources and Hydropower Research, Beijing, China, May 2015.

25. Wang, C.Y. Migration for Reproduction of Chinese Sturgeon (Acipenser sinensis) and Its Habitat Selections in the Yangtze River. Doctoral Thesis, Huazhong Agricultural University, Wuhan, China, June 2012. 
26. Bovee, K.D.; Cochnauer, T. Development and Evaluation of Weighted Criteria, Probability-of-use Curves for Instream Flow Assessments: Fisheries. IFIP No. 3. FWS/OBS-77/63; U.S Fish and Wildlife Service: Washington, DC, USA, 1977. Available online: http://pubs.er.usgs.gov/publication/fwsobs77_63 (accessed on 10 March 2018).

27. Wang, J.N.; Li, C.; Duan, X.B.; Luo, H.W.; Feng, S.X.; Peng, Q.D. The relationship between thermal regime alteration and spawning delay of the four major Chinese carps in the Yangtze River below the Three Gorges Dam. River Res. Appl. 2014, 30, 987-1001. [CrossRef]

28. Zhang, G.; Wu, L.; Li, H.T.; Liu, M.; Cheng, F.; Murphy, B.R.; Xie, S.G. Preliminary evidence of delayed spawning and suppressed larval growth and condition of the major carps in the Yangtze River below the Three Gorges Dam. Environ. Biol. Fish. 2012, 93, 439-447. [CrossRef]

29. Jiang, L.Z.; Ban, X.; Wang, X.L.; Cai, X.B. Assessment of hydrologic alterations caused by the Three Gorges Dam in the middle and lower reaches of Yangtze River, China. Water 2014, 6, 1419-1434. [CrossRef]

30. Duan, X.B.; Liu, S.P.; Huang, M.G.; Qiu, S.L.; Li, Z.H.; Wang, K.; Chen, D.Q. Changes in abundance of larvae of the four domestic Chinese carps in the middle reach of the Yangtze River, China, before and after closing of the Three Gorges Dam. Environ. Biol. Fish. 2009, 86, 13-22. [CrossRef]

31. Zeng, X.S. Study on the promotion of natural reproduction of domestic fish by regulating water rising. Chin. J. Ecol. 1990, 4, 20-23.

(C) 2018 by the authors. Licensee MDPI, Basel, Switzerland. This article is an open access article distributed under the terms and conditions of the Creative Commons Attribution (CC BY) license (http://creativecommons.org/licenses/by/4.0/). 